\title{
HOW TO SELL A POETRY BOOK TWICE? C. TRIBRACHI MUTINENSIS BUCOLICON AD JOHANNEM VITÉZ
}

\begin{abstract}
Summary: Gaspare Tribraco (1439 - ca. 1493) is an almost completely neglected poet despite the fact that his Bucolicon was probably the first collection of eclogues ordered in an elaborate composition during the Quattrocento. Moreover, his eclogues have survived in two different arrangements, thus offering an extraordinary possibility to analyse the humanist poet's methods of poetry book composition. His influence was strong not only among poets who knew Tribraco personally, like Tito Vespasiano Strozzi and Matteo Maria Boiardo. The real importance and impact of his work is reflected by his influence on poets who became part of the Neo-Latin bucolic canon, first of all Baptista Mantuanus. This study is the first attempt to thoroughly analyse the structure of both eclogue collections, as well as Tribraco's relation to classical and medieval pastoral poetry.
\end{abstract}

Key words: Pastoral poetry, Ferrarese humanism, Gaspare Tribraco, John Vitéz, archbishop of Esztergom, Vergil, Calpurnius Siculus, Maximian, Petrarch, Boccaccio, Tito Vespasiano Strozzi, Matteo Maria Boiardo

1. When in the spring of 1465 Janus Pannonius returned to Italy with the Hungarian delegation going to Rome, he also spent some time in his beloved city Ferrara. Although we have no proof, it was most probably there and then that he acquainted himself with Gaspare Tribraco, the young Modenese poet, who, for lack of work in his home town, had been living in Ferrara at least since 1461, enjoying the patronage of Borso d'Este. ${ }^{1}$ Whether Tribraco was a student of Guarino, who died in 1460, cannot be established, but he surely was a very good friend of his son, Baptista Guarino, and most of all of Tito Vespasiano Strozzi. The fact that Tribraco and Janus addressed humorous epigrams to each other proves that they became good friends during Janus' short stay in Ferrara. ${ }^{2}$ It is also quite probable that it was upon Janus' encouragement that Tribraco

\footnotetext{
* The author's research was supported by the Bolyai János Research Grant of the Hungarian Academy of Sciences.

${ }^{1}$ On the biography of Tribraco see VentuRINI, G.: Un umanista modenese nella Ferrara di Borso d'Este: Gaspare Tribraco. Ravenna 1970.

${ }^{2}$ SZALAY-RITOÓK, Á.: Poetischer Briefwechsel von Humanisten. ACD 34-35 (1998-1999) 103.
} 
sent his collection of eclogues with a relatively long, 24-line dedication epigram to John Vitéz, archbishop of Esztergom. There can be no doubts regarding his aim, as more than half of the epigram is devoted to the description of the enormous wealth of Vitéz:

Tribrachi Mutinensis ad Reverendissimum Archiepiscopum Strigoniensem Carmen incipit.

Qua tua non dubites totum volitare per orbem nomina et a Latiis gentibus usque coli, accipe Strigoniae pater et sanctissime praesul, te simul et rebus munera digna tuis.

Accipe Pannoniae iubar indelebile gentis, quae referant nomen tempus in omne tuum.

Tu dare, quod fulvis aurum Pactolus harenis, quod Tagus Hesperio devehit orbe, potes,

et tibi quae patriis opulentia montibus exit, exuperat quantas Croesus habebat opes,

Sardoos lapides, atque altera dona Pyropos, quasque suis gemmas colligit Indus aquis.

Hand ego crediderim tibi maxima dona videri, quae melius per te cessit habenda deus.

Ista rear, cum sis populorum pastor et auctor, ista rear tantum posse decere patrem.

Hic pecudes Poeman armentaque bucera servat, tu populis Poeman, tu pater ille tuis.

Ista rear, paucis quae dii rarissima donant munera longe animo grata futura tuo.

Haec tamen ut vultu amplecti dignere secundo, haec precor ut sacras tangere digna manus, dunque tibi his aliquid resonabit fistula silvis, quod iuvet, haec Tribrachi sint monumenta, pater.

Although Borso d'Este enjoyed chivalric novels written in Italian and French much more than his humanists' Latin poems, ${ }^{4}$ he was indeed a generous patron: already in October 1461 he donated the poet a greater sum, subsidium eundi Venetias et inde in Graeciam pro litteris graecis perdiscendis, even though it is by no means probable that he ever did embark on this journey. ${ }^{5}$ Since December 1464, however, Tribraco

\footnotetext{
${ }^{3}$ Cf. Baptista Guarinus ad Ianum Pannonium, 9-12: Tu nummis certes, fulvoque potentior auro, $/$ ast ego codicibus carminibusque meis, / hoc mihi cuncta modo fient communia tecum, / praecipit ut sanctae foedus amicitiae.

${ }^{4}$ CHLĘDOWSKI, C. vON: Der Hof von Ferrara. Authorisierte Übersetzung aus dem Polnischen von R. SCHAPIRE. München 1919, 64.

${ }^{5}$ CARDUCCI, G.: La coltura estense e la gioventù dell'Ariosto. Bologna 1954, 238.
} 
was already employed as school master in Modena, and although he had students like Antonio Urceo il Codro, he felt himself banned from the lively literary life, and his feeling of not being understood, his personal conflicts and above all his financial difficulties filled him with all the more bitterness. Thus it was during a hard period of his life that he met Janus, and quite possibly he was not just hoping for a reward but also contemplating moving to Hungary (according to the praise of Galeotto: novum Musarum domicilium) ${ }^{6}$ when he sent his eclogues to Vitéz.

2. This is all that can be known as far as the biographical background is concerned. However, Tribraco had every reason to expect that the carefully composed, beautiful codex of seven eclogues - dedicated to Vitéz and decorated with his portrait ${ }^{7}-$ would $^{-}$ prove to be a true literary novelty. As can be proved by numerous allusions in his epistles and speeches, Vitéz much appreciated the bucolic Muse of Vergil. ${ }^{8}$ On the other hand, pastoral poetry had lain dormant for a long time: the allegorising eclogues of Petrarch and Boccaccio did not create a continuous tradition, and even though there had been occasional initiatives, pastoral poetry started to boom and become fashionable again only in the second half of the Quattrocento. ${ }^{9}$ The first experiments in the 1460s can be connected to Naldo Naldi and Leonardo Dati in Florence, and to the circle of friends around Guarino's school in Ferrara. Besides Tribraco, Baptista Guarino, Strozzi and Boiardo also experimented with the renewal of pastoral. Guarino has, however, only written three eclogues, rather as an exercise in style, we know only three of Strozzi's eclogues, although the manuscript tradition suggests that he had written more. ${ }^{10}$ The competing shepherds in Boiardo's Eclogue 7 (Buccula) already regard Tribraco as the master of bucolic poetry, or at least a worthy rival:

si placet alterius certemus viribus ergo;

nam licet et Tribraco certes vel doctior illo, non tamen effugiam.

$(\text { vv. } 28-30)^{11}$

${ }^{6}$ De homine, fol. 87. In ÁBEL, J.: Analecta ad historiam renascentium in Hungaria litterarum spectantia. Budapestini-Lipsiae 1880, 174. $143-144$

${ }^{7}$ On the codex see CSAPODI-GÁRDONYI, K.: Die Bibliothek des Johannes Vitéz. Budapest 1984,

${ }^{8}$ See for example Or. 7. 20: Veterana pestis multum florem magnumque fidelium robur depasta hactenus laedendo crevit et crescendo laesit. The sad dignity of this sentence is strengthened by the allusion to the idyllic refuge of Tityrus: hinc tibi quae semper vicino ab limite saepes / Hyblaeis apibus florem depasta salicti / saepe levi somnum suadebit inire susurro. (Vergil, Ecl. 1. 53-55).

${ }_{9}^{9}$ Kegel-BrinKGreve, E.: The Echoing Woods. Bucolic and Pastoral from Theocritus to Wordsworth. Leiden 1990, $284 \mathrm{ff}$. On the reception of Petrarch in the Quattrocento see HANKINS, J.: Petrarch and the Canon of Neo-Latin Literature. In Petrarca, l'Umanesimo e la civiltà europea [Atti del Convegno Internazionale, Firenze, 5-10 dicembre 2004]. A cura di D. COPPINI e M. FEO. Quaderni petrarcheschi 1718 (2007-2008) 905-922.

${ }^{10}$ Titus VesPasianus StRozzi: Borsias (Fragmenta) - Bucolicon liber. Edd. I. FóGeL - L. JuHÁsZ. Lipsiae 1933, 3.

${ }^{11}$ For a detailed analysis of these lines see the introduction of S. Carrai: Matteo Maria Boiardo: Pastoralia. Testo critico, commento e traduzione di S. CARRAI. Padova 1996, 68-70. 
In view of this it is somewhat surprising that these poems have almost completely been neglected by scholars of pastoral poetry. Whether in comprehensive works on the history of the pastoral genre, or in works on the literature of Ferrarese humanism, the poet is seldom mentioned in a few lines. The main reason for this may well be that the editio princeps published by the young Hungarian scholar, Jenö Ábel, in $1880,{ }^{12}$ who collected the humanist sources relating to Hungary, hardly became known. To mention just two examples: both W. L. Grant's comprehensive monograph on Neo-Latin pastoral and W. Ludwig's epochal edition of Borsias published in 1980 refer to Tribraco's eclogues as unedited texts, ${ }^{13}$ and even Giuseppe Venturini himself makes no mention of Ábel's edition in his book on Tribraco published in 1970. He only learned of Ábel's edition years later while preparing his own. ${ }^{14}$

All three poets, Tribraco, Strozzi and Boiardo, wrote their pastoral poems at the very beginning of the $1460 \mathrm{~s}$, reflecting upon each other's work, ${ }^{15}$ so that it is almost impossible to define the chronological order of the eclogues due to the very short time span under consideration. Yet there can be no doubt that the first collection of eclogues ordered in an elaborate composition during the Quattrocento was that of Tribraco. Moreover, his eclogues have survived in two different arrangements, thus offering an extraordinary possibility to analyse the humanist poets' methods of poetry book composition.

3. Tribraco's Bucolicon survived in three codices: the codex Bononensis (a colligatum containing the works of Modenese poets), the Modenensis, which contains three poetic works of Tribraco: De velocitate temporis, Epigramma in divum Borsium, Bucolicon, all dedicated to Borso d'Este, and the Codex Budapestinensis, containing only the Bucolicon in the same arrangement as in the Modenese codex, but this time dedicated to the archbishop of Esztergom. ${ }^{16}$ Both the composition in the codex Bononensis and the redaction of those dedicated to Borso d'Este and then to Vitéz contain seven eclogues, yet in an absolutely different order, both containing one eclogue missing from the other collection. According to Venturini, the different order is simply due to the fact that Tribraco had also published the eclogues separately, which were then randomly ordered, not necessarily following the author's intentions. ${ }^{17}$ In our view, both compositions result from a very careful planning. This is supported by the fact that in both cases the poet included exactly seven eclogues, obviously following the artful composition of the seven eclogues of the Neronian poet T. Calpurnius Siculus,

\footnotetext{
${ }_{13}^{12}$ See n. 6 .

${ }^{13}$ Grant seems to be ignorant of the Codex Budapestinensis and only mentions the Ferrarese and Bolognese manuscripts: GRANT, W. L.: Neo-Latin Literature and Pastoral. Durham 1965, 119; LUDWIG, W.: Die Borsias des Tito Vespasiano Strozzi. Ein lateinisches Epos der Renaissance. München 1977, 32.

${ }^{14}$ Venturini, G.: Il Carmen Bucolicum di G. Tribraco. GFF 1 (1978) 95.

${ }^{15}$ It is noteworthy that, according to Carrara, a shepherd, the lover of Galanthis in Strozzi's Eclogue 3, whose name is Tribalus, can most likely be identified with Tribraco himself: CARRARA, E.: La poesia pastorale. Milano 1909, 249. Strozzi also dedicated an elegy with a strong pastoral colouring to Tribraco (Eroticon 4. 22).

${ }^{16}$ For a detailed description of the three manuscripts see VENTURINI (n. 14) 94-100.

${ }^{17}$ Venturini (n. 14) 97.
} 
who became a highly esteemed author in the second half of the Quattrocento. ${ }^{18}$ Like Calpurnius, Tribraco also placed the eclogue describing the blissful effects of the ruler's ascent to the throne in the middle of the Bononensis version, which is then surrounded by two times three eclogues according to the principle of ring composition. Tribraco namely wrote his Eclogue 4 (Phorbas) in 1463 on the occasion of Ercole d'Este's accession as Duke of Modena.

The poem placed in the middle divides the collection in two thematic parts. The first three eclogues are about love, the other three about the poverty and the defenceless situation of the client-poet. The representation of this delicate relation is one of the most important themes of Renaissance pastoral poetry, ${ }^{19}$ inspired above all by Calpurnius' Eclogue 4. In this poem Corydon, the poet's alter ego, asking for a villa, a smaller property and the continuing support of his literary career as a reward for his song celebrating Nero, can be interpreted as the self portrait of the poverty-stricken artist at the mercy of his rich patron, drawn with bitter irony. ${ }^{20}$ This often vitriolic tone is not absent from Tribraco's eclogues either.

The two thematic groups are ordered in a way that the tone of the eclogues further from the central one, depicting the blissful return of the Golden Age, is more and more disharmonic. In the singing contest of Eclogue 3 Philonicus and Alcon, two carefree and happy shepherds, compete in the praise of the beloved ones. In Eclogue 2, however, the shepherds can just about save the unlucky fellow Menalcas, who hung himself out of love sickness, while the hero of Eclogue 1, Thyrsis, is bemoaning the sudden death of his beloved Galanthis. The situation is obviously similar within the second group of poems: in Eclogue 5 Poeman enjoys protection even amidst the harsh conditions of the world and can devote himself to poetry, while in Eclogue 6 a shepherd grown old in poverty and looking back upon his youth with bitter nostalgia recalls the song he wrote as a young man about the story of Polyphemus and Galatea. In the course of time, however, the never ending poverty had broken his soul, evoking Calpurnius' hero, Corydon, who reluctantly realizes the uselessness of poetry and advises his younger brother trying to play the pipe to rather go to the town and sell milk:

\author{
Ah, procul, ah procul haec! Memini, cum iunior essem, \\ liberiorque animo, sic me lasciva iuvabant, \\ ut caper assidens placidis e more capellis \\ iniceret facilem domino quandoque salivam. \\ Nunc autem, quo me fugerunt otia, duri \\ iamdudum mentem et corpus fregere labores \\ huius et infirmi pecoris me cura iacentem
}

\footnotetext{
${ }^{18}$ On the reception of Calpurnius see SIMON, L. Z.: "Sacra Calpurni vestigia." Calpurnio Siculo e i nuovi percorsi della bucolica umanistica nel secondo Quattrocento. SUP 27 (2007) 157-176.

${ }^{9}$ Still useful on this subject is KRAUTTER, K.: Imitatio und Probleme des Dichterberufes in den Eklogen des portugiesischen Neulatiners Henrique Caiado. Arcadia 6 (1973) 248-273. More recently see FETKENHEUER, K.: Hungernde Dichter, unwillige Mäzene. Baptista Mantuanus' Ekloge V und die römische Satire. Philologus 156 (2012) 310-327.

${ }^{20}$ si quando montibus istis / dicar habere Larem, si quando nostra videre / pascua contingat! vellit nam saepius aurem / invida paupertas et dicit:'ovilia cura!' (IV. 154-56)
} 
opprimit: invideo gelida tellure sepultis.

Nam quid agam, lactis si copia nulla nec usquam

vellera nec fetus legimus tot matribus ullos?

quid sperare licet? Timeo, ne funditus omnis

grex pereat quando omnis ager, quando omnis in illo

spes mea; non ervum mihi dant spatiosa Brabanti

iugera, non segetes alio quoque rure relictas

plaustra vehunt; pecus hoc quodcumque pecunia nostra est

$$
(\text { vv. 85-95) })^{21}
$$

Finally, in the closing Eclogue 7 we hear the complaints of a young shepherd suffering from his wicked stepmother, the angry Sterope, and who in his poverty has no chance whatsoever to marry his beloved, the golden haired Ciris.

4. This very appealingly composed collection is completely re-organised in the version Tribraco dedicated to Borso and then to Vitéz, yet, in our opinion, this arrangement is also based on similarly conscious considerations. Tribraco removed the Eclogue entitled Phorbas celebrating Ercole d'Este's governorship and replaced it with the Eclogue entitled Daphnis, which was missing from the other version. This poem is originally the praise of Borso d'Este, following Vergil's Eclogue 4 and mainly 5, yet the allegory is so general that it can perfectly be interpreted without reference to anyone specific. He placed this poem not in the middle of the collection but at its end. This re-ordering was surely also a result of his striving for self-correction: the only flaw of the original composition was namely that the eclogue containing the conversation between Poeman and Aepolus, originally Eclogue 5, is unproportionately long, made up of 173 lines, whereas the other eclogues are roughly of the same length, varying between 98 and 112 lines. ${ }^{22}$

In the new volume, then, it is the longest eclogue that is placed at the beginning. This eclogue seems to be made up of two poems of the same length but on radically different subject matters: the first half of the poem, the conversation between Aepolus and Poeman, is about a poet enjoying the support of a patron, the second part is a love complaint rewriting the lamentation of Polyphemus in Ovid's Metamorphoses, Book 13. In this way the eclogue forecasts and summarises the contents of the whole composition. The first half of the eclogue paraphrases Vergil's Eclogue 1. Like Tityrus, Poeman also enjoys complete peace in the valley hidden from the world, and can devote himself to poetry only, while there are towns burning and people whining and crying all around. And like Meliboeus, who had been driven away from his land, the bony Aepolus herding his sheep in despair also wonders at this exceptional state.

${ }^{21}$ Cf. Calpurnius, Ecl. 4. 22-28: Dicentem, Corydon, te non semel ista notavi: / "frange, puer, calamos et inanes deseree Musas, / i, potius glandes, rubicundaque collige corna, / duc ad mulctra greges et lac venale per urbem / non tacitus porta. Quid enim tibi fistula reddet, / quo tutere famem? certe mea carmina nemo / praeter ab his scopulis ventosa remurmurat echo."

${ }^{22}$ Note that the ten Latin eclogues of Boiardo (Pastoralia) are all composed of exactly 100 lines, probably with the aim to surpass Tribraco in accurateness. 
Moreover, apart from the length of the poem there may well have been a more important reason for Tribraco's decision to place this eclogue at the beginning of the new volume.

It is well known that the poets of the Trecento regarded allegory as the most important, decisive element of pastoral. According to this concept, every single detail of the text carries some hidden meaning and can be interpreted only with the help of a code. In the school of Guarino, however, a basically different point of view came to be accepted, based on Servius' critique of some extreme allegorical interpretations. ${ }^{23}$ This new concept which - transcending the bounds of strict allegoresis and opening the "Weg der poetischen mimesis" ${ }^{24}$ - later became fully established in the Adulescentia of Baptista Mantuanus, in the eclogues of Pontano and in Sannazaro's artful Eclogae piscatoriae. At several points of Tribraco's collection his knowledge of Petrarch and Boccaccio can be proved by textual correspondences, ${ }^{25}$ and we also find traces of the extreme tendency towards allegorisation. The Petrarch-allusion in Eclogue 3 (fontes hoc nempe loquuntur, / hoc nemora et montes, 32-33), for example, obviously refers to the mighty (montes) and the scholars (fontes) ${ }^{26}$ But it is more often the case that Tribraco places an expression of Vergil that has a conventional allegorical interpretation in a context which, against the readers' expectations, renders the allegorical interpretation impossible. Already the ancient commentaries equated the ten golden apples mentioned in Vergil (aurea mala decem misi, cras altera mittam, 3. 71) with the ten eclogues, provoking the cutting remark of Servius ad loc.: quae enim necessitas hoc loco allegoriae? We often meet this symbol in the works of humanist authors

\footnotetext{
${ }^{23}$ Servius points out already in the very first line of Eclogue 1 that: "et hoc loco Tityri sub persona Vergilium debemus accipere, non tamen ubique, sed tantum ubi exigit ratio", because "Refutandae sunt allegoriae in bucolico carmine, nisi cum ... ex aliqua necessitate descendunt." Ad Ecl. III. 20. On pastoral allegory in general see PATTERSON, A.: Pastoral and Ideology. Virgil to Valéry. Oxford 1988; CHAUdHURI, S.: Renaissance Pastoral and its English Developments. Oxford 1989. On the Scuola Guariniana and the new concept of bucolic poetry see TISSONI-BENVENUTI, A.: La restauration humaniste de l'églogue: L'école guarinienne à Ferrare. In Le genre pastoral en Europe du XV $V^{e}$ au XVII siècle [Actes du Colloque internationale tenu à St. Étienne du 28 septembre au 1er octobre 1978]. St. Étienne 1980, 25-34; STRACKe, M.: Klassische Formen und neue Wirklichkeit. Die lateinische Ekloge des Humanismus. Würzburg 1981, 10.

${ }^{24}$ KRAUSS, W.: Über die Stellung der Bukolik in der ästhetischen Theorie des Humanismus. In Europäische Bukolik und Georgik. Hrsg. von K. GARBER [Wege de Forschung 355]. Darmstadt 1976, 145.

${ }^{25}$ Ecl. IV. 67-69: Haud sua figebat medio vestigia campo / certa satis, pedibusque labans hac ibat et illac / lubricus, ut sparso pluviis qui limite currit. Cf. Boccaccio, Bucc. carm. 15. 36-38: Hinc imbres quatiunt miserum lubricumque fatigat / inde solum: nunc terga tibi nunc pectora nudat / infestus Boreas... Ecl. 1. 169-172: Interea quando saturas monet hora capellas / claudere et expectant matres in ovilibus agni, / lucidaque in summo fulgescunt sydera caelo, / nec procul ire licet... Cf. Boccaccio, Bucc. carm. 9. 197-198: Nox atra venit; iam sydera caelo surgere nonne vides?; 16. 143-144: Surgunt ex montibus altis / sydera: sis mecum ...

${ }^{26}$ Cf. Petrarch, Buc. carm. 1. 8-10: Quis vel inaccessum tanto sudore cacumen / montis adire iubet, vel per deserta vagari / muscososque situ scopulos fontesque sonantes? According to the author's commentary: inaccessum cacumen... famae rarioris et ad quam pauci perveniunt, altitudo est. Deserta... sunt studia; haec vere deserta hodie... muscosi scopuli sunt potentes ac divites, fontes sonantes literati et eloquentes homines dici possunt (Fam. X. 4). Cf. Collatio laureationis 9. 8: Eo tamen dulcior fit poesis, quo laboriosius quesita veritas magis atque magis inventa lucescit.
} 
- Tribraco's contemporary, Naldi, also refers to Vergil's ten eclogues this way ${ }^{27}-$, in Tribraco, however, it appears among the votive gifts offered for the fertile year, the mug of milk (sinum lactis), the fat lambs (pingues agni) and the fells of beasts (variarum terga ferarum), alluding to the votive epigrams of Corydon and Thyrsis in Vergil's Eclogue 7:

Cum deus hunc sterilem mihi fecundaverit annum, tunc sinum lactis tribuemus et aurea mala, tunc dabimus pingues atque aequos matribus haedos, captaque venando variarum terga ferarum. (vv. 95-98)

The rejection of strict allegorisation is also reflected by the fact that there are historical persons as well as not allegorical, purely fictive ones among the figures of the eclogues, just like in Vergil and Calpurnius. It is also completely in accordance with Servius' principle "non ubique" that in Eclogue 3 Phileros can no doubt be identified with Borso d'Este, in Eclogue 7, however, Borso appears under another name, as Daphnis, whereas the Daphnis of Eclogue 4 is a simple shepherd, who hurries with his friends to save Menalcas, just stringing himself up on a tree.

5. This Vergilian play with identity and difference makes it difficult to identify the main figure of Eclogue 1. The far too general characterisation allows the reader to identify Poeman with the author himself, as G. Venturini does, or else with Strozzi, as W. Ludwig does. Yet it was exactly the palpable character of allegory that allowed Tribraco to accompany the collection with an epigram of dedication which, by stressing that Vitéz was a shepherd (poeman) himself, so to say prescribes the so far unfixed code of the interpretation of the text, and defines the scene as the allegory of Hungary threatened by the pagan Turks (rura, urbesque ardent), and of the activities of Vitéz as a priest (tutos pavisse greges), a statesman (rura urbes florere facis), and a humanist scholar (praedoctus). As the figure of Poeman can be connected to Vitéz, so will the miserable Aepolus naturally be identified with the author asking for financial support:

\section{Tribrachi Mutinensis ad Reverendissimum Archiepiscopum Strigoniensem}

Poeman, Aepolus, Pastores.

Aepolus

O nitidi pecoris dux, Poeman, vallibus unde, unde tibi his campis, quos depopulantur ab omni

\footnotetext{
${ }^{27}$ Niteris id, sacri quondam quod Musa Maronis, / qui cecinit ludens aurea mala decem. Elegiae ad Laurentium Medicen, 2. 29. (Ad Amerigum Corsinum eclogas scribere incipientem) 3-4.

${ }^{28}$ Cf. Vergil, Ecl. 7. 29-36: C. Saetosi caput hoc apri tibi, Delia, parvus / et ramosa Micon vivacis cornua cervi. / si proprium fuerit, levi de marmore tota / puniceo stabis suras evincta coturno. / Th. Sinum lactis et haec te liba, Priape quotannis / exspectare sat est: custos es pauperis horti. / nunc te marmoreum pro tempore fecimus; at tu, / si fetura gregem suppleverit, aureus esto.
} 
parte lupi, tantam licuit captare quietem? Rura, urbesque ardent, hic tu securus in umbra rura, urbes florere facis; latus omne resultat planctibus, ipse levi praedoctus arundine silvas et montana trahis resonare cacumina tecum.

O nimium felix pecus, o pecorumque magister, cui datur in media mundi cessare ruina, et tutos pavisse greges et flumine pastos mergere et ad mulctram iam sero in vespere ductos quot prius e stabulis puer enumerarat euntes, claudere lacte graves ac tempore foetibus ipso. Diis potes, o Poeman, geminos offerre quotannis, diis potes et debes geminos cum matribus agnos qui te respiciunt.

Returning now to the composition of the book, we also have a ring structure in this version. Instead of Eclogue 4 praising Ercole d'Este, however, it is the comical-satirical eclogue about Menalcas' suicide that is placed in the middle. It is surrounded by two times two eclogues, yet exactly in the opposite order as before. Fully in line with the dedication epigram addressed to Vitéz, Eclogue 1 is followed by the two poems which originally stood at the end of the collection, giving a detailed and pitiful picture of the poet's exasperating poverty, whereas the two love eclogues, the singing contest and the mourning of Galanthis, appear as the fifth and sixth piece. The closing poem entitled Daphnis is new. Its hero is the opposite of the love stricken Daphnis known from mythology: although every nymph longs after him, although they crown him with daffodils and hyacinths while he is asleep, and make him a bed of flowers, this Daphnis is not mastered by the passion of love like all the other common shepherds. His only pleasure is hunting, and among the nymphs he pays some attention only to Eutyche, who faithfully accompanies him everywhere, and who is, naturally, none other than the allegory of good fortune. It is not difficult to decipher the allegory, it is well known that Borso d'Este never married, according to the official explanation so as not to further complicate the situation of the legitimate heirs, Ercole and Sismondo, and that he was a passionate hunter - perhaps it is not fortuitous that Diana so often appears in the poems of the Ferrarese poets, including Tribraco. ${ }^{29}$ In the context of the new composition, however, these biographical traits lose their significance. Daphnis becomes the personification of passionlessness, the perfect opposite of the tragicomic lover hanging himself in Eclogue 4:

Mox agitare feras, omnes percurrere montes, omne nemus studiis agitare virilibus amnes et saltu superare suo torrentior ipse

${ }^{29}$ A beautiful example is the scene of Pontano's visit among the nymphs of Diana in Strozzi's Borsias (5. 368 sqq.), which contains an originally independent poem entitled Lucilla nympha Rechanensis, Carm. 1. 
fluminibus rapidis, qualis Peleius heros Peliacis olim iuvenem se exercuit antris aspera semiferi capiens praecepta magistri.

Hunc Dryades unum ardebant hunc Naiades omnes, florea florilegae texebant serta Napaeae.

Harum una Eutyche iuvenem quocumque secuta est illius et lateri semper comes haesit amica duxque fuit quacumque viam venando pararet nec ferus incauto dira in discrima passu curreret aut umeris etiam maiora subiret, qualis formosum dea Cypris Adonin et Phrygium qualis puerum Berecynthia mater.

The new composition - or to use a more revealing term perhaps, the new hypernarrative - thus radically changes the range of possible interpretations: the whole volume is built upon the opposition of devastating passion and blissful passionlessness.

6. Both in the satirical representation of love and in placing the summarising eclogue, almost three times as long as the others, at the beginning of the volume, Tribraco may also have been influenced by Maximian, the Late Antique elegist, who remained a school author throughout the Middle Ages because of his moralising tone, his satirical sense of humour and the fluency of his language. ${ }^{30}$ The collection that has survived under his name consists of six elegies. The 292-line opening elegy about the old man looking back on his love affairs with a somewhat bitter nostalgia is followed by five elegies, all significantly shorter than the opening one, each of which elaborates on a topic listed in Elegy $1 .{ }^{31}$ Our hypothesis is further supported by several textual correspondences between the eclogues of Tribraco and the elegies of Maximian. ${ }^{32}$ The most beautiful one is the description of Galanthis, taken by death at such a young age, in Eclogue 6, which conspicuously relies on the passages of Maximian's Elegy 1, containing naturally a number of Ovidian allusions, in which the narrator talks about the kind of women he liked when he was young:

\section{Nulla superbit}

par facie his virgo silvis neque montibus ulla omnibus in Latiis. Heu, me meminisse dolori est

\footnotetext{
${ }^{30}$ On Maximian recently see SCHNEIDER, W. CHR.: Die elegischen Verse von Maximian. Eine letzte Wiederrede gegen die neue christliche Zeit. Mit den Gedichten der Appendix Maximiana und der Imitatio Maximiani [Palingenesia 79]. Stuttgart 2003.

${ }^{31}$ SpaltensteIn, F.: Commentaire des élégies de Maximien. Institut Suisse de Rome 1983, 68

${ }^{32}$ Even the riddle at the end of a singing contest imitating Vergil's Ecl. 3. 104-107 derives from Maximian: Dic mihi tu: titulumque velim tibi quemlibet addas, / mox ubi rettuleris si forte probabile reddes / esse, quod hoc animal credas quod repere primum / incipit ut quadrupes, pedibus mox ambulat aequis? (Ecl. 5 89-92) Cf. Maximian 1. 217-220: Nec caelum spectare licet, sed prona senectus / terram qua genita est et reditura videt / fitque tripes prorsus quadrupes ut parvulus infans / et per sordentem flebile repit humum.
} 
qualibus aspiciens me illustrabat ocellis, ut fulvum auratis superabat crinibus aurum Paestanisque rosis velut aemula labra gerebat, illius ut roseos flammabat purpura vultus molle ebur utque etiam vincebat lactea cervix. O teretes digitos nivibusque simillima canis bracchia! Vix nitidis pedibus formosa Galanthis incedens calcare solum quaque ibat et illac lilia surgebant et regia nomina flores vernabatque omnis circum vestigia tellus.

The figure of Theradamas, the bitter old man remembering the frivolous songs of his youth in Eclogue 2, was also inspired by Maximian, whose influence is also reflected by the moralising tone, the use of many maxims and proverbs, ${ }^{34}$ as well as by the realistic, even strongly satirical description of the state of mind of young men madly in love:

Mirabar, velut ille macer tenuaverat artus,

iamque fere totus totus [sic!] miserabile cornu.

Haud sua figebat medio vestigia campo

certa satis pedibusque labans hac ibat et illac

lubricus ut sparso pluviis qui limite currit.

Saepe mihi occurrit mediis num sentibus hydrum

calcasset miser ille, miser num forsitan umbras,

dum nemorum secreta petit, vidisset iniquas.

While Petrarch still meticulously tried to avoid textual similarities with ancient authors, and upon re-reading his works altered the sentences that reminded of a well-known ancient passage, ${ }^{35}$ the lines in Tribraco taken over almost unaltered from Vergil and

${ }^{33}$ Cf. Maximian 1. 89-98: Candida contempsi, nisi quae suffusa rubore / vernarent propriis ora serena rosis. / Hunc Venus ante alias sibi vindicat ipsa colorem, / diligit et florem Cypris ubique suum. / Aurea caesaries dimissaque lactea cervix / vultibus ingenuis visa sedere magis. / Nigra supercilia, frons libera, lumina nigra / urebant animum saepe notata meum. / Flammea dilexi modicumque tumentia labra, / quae gustata mihi basia plena darent. Very similar descriptions are to be found in Strozzi (Eroticon 3. 71-77) and in Boiardo (Pastoralia 5. 60-84), compared and analysed by BIGI, E.: La poesia latina di Boiardo. In Il Boiardo e la critica contemporanea [Atti del Convegno di Studi su Matteo Maria Boiardo Scandiano - Reggio Emilia, 25-27 Aprile 1969]. A cura di G. ANCESCHI. Firenze 1970, 81-96, however, the Italian scholar makes no mention of Tribraco's Eclogue 6.

${ }^{34}$ A good example is the abundance of proverbs in the comforting speech of Philondas in Ecl. 2. 99-112: Non, bone Theradama, non semper nubibus aer / cingitur, haud crepitant metuenda tonitrua semper, / saepe suis vidi viduari frondibus ulmos, / vidi etiam quassas ego mox revirescere frondes; / usque licet speres in diis praesentibus usque; / non hodie annuerint esto, non crastina surdi / vota secundabunt, iterumque rogabis / pulsabisque fores, donec prece victa dehiscet / ianua, dum tandem tibi fors ridebit et ipsum / teque tuumque pecus Rex fortunaverit ille / qui vitam, qui donat opes, qui gestat in ipsis / fortunam prudens manibus vincique benignus / assuevit. Deus ille aderit, deus ille favebit; / tu modo Theradama, sperando perge precari.

${ }_{35}$ Quod hodiernum erat, est decima pastorii carminis egloga, cuius quadam in parte ita scripseram: "solio sublimis acerno"; postmodum vero dum relegeretur, attendi simile nimis esse virgiliano carmini; ille enim ait in septimo divini operis: "solioque invitat acerno". Mutabis ergo et loco illius pones ita: "e se- 
Ovid, clausulae such as Berecynthia mater (7.42), ${ }^{36}$ lines like "nubiferumque caput magis abdidit Appenninus" $(6.58)^{37}$ not only serve the higher stylistic qualities of the text but are also meant to prove that the young poet is perfectly acquainted with the literary tradition and is ready to try his talent as court poet in higher genres. Tribraco uses - again unlike Petrarch, Boccaccio and even Strozzi - only shepherds' names from ancient pastoral poetry (Thyrsis, Alcon, Aegon, Theradamas), ${ }^{38}$ furthermore, he consciously aims at decorating his eclogues with mythological names that only rarely appear even in classical poetry. A good example comes from Eclogue 1 where Aepolus, who can be interpreted as the author's alter ego, compares the beauty of Callirhoe praised by Poeman to the nymphs of his home land:

Vera loquar, Poeman, nymphas ego mille secutus collibus in patriis Cianemque et Callianeram, Pandroson et quales non quivis novit amicas.

The phrase "quales non quivis novit amicas" can be interpreted as ambiguous, it does not only refer to the beauty of Modenese girls, but - just like the above mentioned description of Galanthis, which is also a place for poetic memory $-{ }^{39}$ is meant to demonstrate the author's exceptional erudition, as there are surely not many who would know the catalogue of nymphs from the Iliad (18. 39-49) where Kallianeira is mentioned, and perhaps not everyone remembers Pandrosos and Cyane from the Metamorphoses (2. 559; 5. 407-464).

7. The decisive influence of Maximian, however, demonstrates the strong presence of the medieval poetic canon in the eclogues of Tribraco, behind the obviously classicising features. The description of Callirhoe in Eclogue 1 evokes the complaints of Polyphemus addressed to Galatea in Metamorphoses, Book 13, but next to the Ovidian comparisons - maturis dulcior uvis, candidior ligustris, crudelior orba tigride we also find ones originating from the Vulgata, for example from Psalm 57 (truculentior aspide surda $),{ }^{40}$ while the above mentioned description of Galanthis ends with an allusion to Prudence, evoking the dance of the happy souls from the famous

de verendus acerna". Fam. XXII. 2. 22. This passage and some others of similar interest are discussed by PIGMAN III, G. W.: Neo-Latin Imitation of the Latin Classics. In Latin Poetry and the Classical Tradition, Essays in Medieval and Renaissance Literature. Ed. by P. GOODMAN and O. MURRAY. Oxford 1990, 199-210.

${ }^{36}$ Vergil, Aen. 6. 784.

${ }^{37}$ Ovid, Met. II. 226.

${ }^{38}$ In the Bucolicum carmen of Petrarch we find, for example, Silvius, Monicus, Martius, Multivolus, in Boccaccio's Buccolicum carmen: Montanus, Florida, Silvius, Olympia, Appenninnus, in Strozzi's Bucolicon: Zephyrinus, Chronidon, Albicus, Tribalus.

${ }^{39}$ Séris' appropriate remark on a similar passage in Poliziano's Ode 8 seems to be valid for Tribraco: "Galatée, la nymphe fugitive, était donc déja chez Virgile un symbole de la réminiscence poétique. Pour Politien, Galatée est plus précisement l'image de la beauté des textes passés que la poète s'efforce de rappeler à sa mémoire et de fixer dans celle des ses auditeurs." SÉRIS, É.: Galatée chez Ange Politien: une image de mémoire de la poésie antique. BHR 62 (2000) 606.

${ }^{40}$ furor illius secundum similitudinem serpentis, sicut aspidis surdae et obturantis aures suas, quae non exaudiet vocem incantantium... (57. 5) 
hymn Inventor rutili. ${ }^{41}$ In his eclogues, then, besides the vindication of the humanist ideal of cultivation and the adoption of the new concept of pastoral, Tribraco did not strive to radically break with the medieval literary tradition, as can be observed in many works of the probably most strongly classicising genre of bucolic poetry in the Quattrocento and later. And exactly due to his synthesising these two traditions could he overcome the limits of a merely reproductive imitation.

Although his eclogues were quickly forgotten and were never published in print, their influence was strong not only among contemporary poets who may have known Tribraco personally, as the likewise Modenese Panfilo Sasso, author of very witty epigrams, the excellent elegist Marcantonio Aldegati living in Mantova, or Raffaele Zovenzoni, a humanist of distinction at Triest. The real importance and impact of his work, however, is reflected by his influence on poets who became part of the Neo-Latin bucolic canon, first of all Baptista Mantuanus. ${ }^{42}$

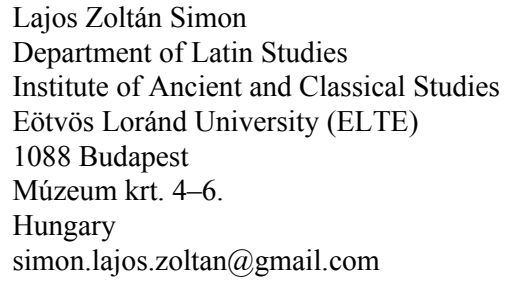

${ }^{41}$ Illic, purpureis tecta rosariis / omnis fragrat humus, caltaque pingia / et molles violas et tenues crocos / fundit fonticulis uda fugacibus. / Illic et gracili balsama surculo / desudata fluunt, raraque cinnama / spirant, et folium, fonte quod abdito / praelambens fluvius portat in exitum. / Felices animae prata per herbida / concentu pariles suave sonantibus / hymnorum modulis dulce canunt melos, / calcant et pedibus lilia candida. (Cath. 5. 113-124)

${ }^{42}$ On Tribraco and Mantuanus see my earlier paper: Simon, L. Z.: Die Eklogen des Gaspare Tribrachus und die neue Blütezeit der Bukolik. In Pietas non sola Romana. Studia memoriae Stephani Borzsák dedicata. Ed. by A. CZEGlÉDy, L. HorvÁTH, E. KRÄHLing, K. LACZKÓ, D. Á. Ligeti, GY. MAYER. Budapest 2010, 632-647. 
